\title{
Science Process Skills in the Greek Primary School Science Textbooks
}

\author{
Andriani Sideri', Michael Skoumios²* \\ ${ }^{1}$ School of Humanities, Hellenic Open University, Patra, Greece, ${ }^{2}$ Department of Primary Education, School of Humanities, University of the Aegean, \\ Rhodes, Greece
}

*Corresponding Author: skoumios@rhodes.aegean.grc

\section{ABSTRACT}

Science process skills play an essential role in science education. The research assessing these skills in school science textbooks is limited. The aim of the current study was to examine the involvement of science process skills in the content of science school textbooks of the last two primary school grades in Greece. A specific analysis framework was adopted, based on 534 activities included in the two textbooks. It was concluded that the activities included in the two textbooks mainly involved the skills of communicating, observing, and inferring, while the involvement of the remaining science process skills was particularly limited. Therefore, the school textbooks fail to provide students satisfactory opportunities to engage in science process skills and facilitate a better understanding of sciences ideas and concepts. The findings of this study provide information about some strengths and weaknesses of the science textbooks that could be used by teachers in planning for teaching.

KEY WORDS: science process skills; school textbooks; science education

\section{INTRODUCTION}

D uring the last decades, a part of the research held in the field of science education has taken an interest not only in the knowledge that students of both primary and secondary education acquire but also in the science process skills they develop (Kruit et al., 2018a). It has been established that these skills are largely associated with students' scientific literacy, their familiarity with the nature of science, as well as their academic achievements in science (Shahali et al., 2017).

In the past few years, many countries have implemented several reforms to their national school curricula, as far as the latter's goals and content are concerned, for the teaching of science to contribute to the development of science process skills among students of both primary and secondary education levels (Beaumont-Walters and Soyibo, 2001; Dökme and Aydınl,, 2009; Kruit et al., 2018b; Shahali et al., 2017). Furthermore, on grounds of the crucial role that school science textbooks hold, being a fundamental part of both the teaching and learning procedures (McDonald, 2016), it has been noted that they should provide students with opportunities to use and develop science process skills (Yang et al., 2019).

Although the importance of students' involvement in science process skills has been well acknowledged (Kruit et al., 2018a; Özgelen, 2012; Tilakaratne and Ekanayake, 2017; Zeidan and Jayosi, 2015), the amount of research focusing on the inclusion of science process skills in the content of school textbooks is rather limited (Yang et al., 2019). Therefore, the need for more research to be conducted in this particular area arises. The present study examined the activities included in Greek science school textbooks of the last two primary school grades with the aim to investigate to what extent these involve science process skills.

\section{THEORETICAL BACKGROUND}

\section{Science Process Skills}

The term science process skills (SPS) refers to the main skills employed by scientists when they conduct scientific research, which aims to address a scientific problem and provide explanations on natural world phenomena (Feyzioğlu et al., 2012; Kruit et al., 2018b; Maranan, 2017; Özgelen, 2012). However, the development of SPS is considered essential not only to scientists but also to students for them to achieve a better understanding of science content (Kruit et al., 2018b; Maranan, 2017; Miles, 2010; OECD, 2017).

A proposal classified SPS under two main categories - namely the basic SPS and integrated SPS - whereas the development of the former is to be considered as the necessary building block for the development of the latter (Brotherton and Preece, 1995; Chabalengula et al., 2012; Padilla, 1990). Other researchers, however, incorporate these two categories into a single integrated set of skills (German et al., 1996; Yang et al., 2019). Table 1, presents the SPS along with a brief description.

The development of students' SPS constitutes a substantial objective of science education, since it has been pointed out that students' involvement in them stands as a groundwork for the development of their understanding of science ideas 


\begin{tabular}{|c|c|}
\hline Skills & Description \\
\hline Observing & $\begin{array}{l}\text { Using the senses to gather information } \\
\text { about an object or event }\end{array}$ \\
\hline Inferring & $\begin{array}{l}\text { Making an educated guess about an object } \\
\text { or event based on previously gathered data } \\
\text { or information }\end{array}$ \\
\hline Measuring & $\begin{array}{l}\text { Using standard and nonstandard measures } \\
\text { or estimates to describe the dimensions of } \\
\text { an object or event }\end{array}$ \\
\hline Communicating & $\begin{array}{l}\text { Using words or graphic symbols to } \\
\text { describe an action, object or event }\end{array}$ \\
\hline Classifying & $\begin{array}{l}\text { Grouping or ordering objects or events } \\
\text { into categories based on properties or } \\
\text { criteria }\end{array}$ \\
\hline Predicting & $\begin{array}{l}\text { Stating the outcome of a future event } \\
\text { based on a pattern of evidence }\end{array}$ \\
\hline Controlling variables & $\begin{array}{l}\text { Identifying variables that can affect an } \\
\text { experimental outcome, keeping most } \\
\text { constant while manipulating only the } \\
\text { independent variable }\end{array}$ \\
\hline Defining operationally & $\begin{array}{l}\text { Stating how to measure a variable in an } \\
\text { experiment }\end{array}$ \\
\hline Formulating Hypothesis & $\begin{array}{l}\text { Stating the expected outcome of an } \\
\text { experiment }\end{array}$ \\
\hline Interpreting data & $\begin{array}{l}\text { Organizing data and drawing conclusions } \\
\text { from it }\end{array}$ \\
\hline Asking questions & Raising an appropriate question \\
\hline Formulating models & $\begin{array}{l}\text { Creating a mental or physical model of a } \\
\text { process or event }\end{array}$ \\
\hline
\end{tabular}

and concepts (Bell et al., 2012; Miles, 2010; NRC, 2012; OECD, 2017).

In fact, acquiring SPS is considered essential not only for students intending to follow a science related profession but also for every other individual citizen (Çakır and Sarıkaya, 2010; Maranan, 2017). Citizens equipped with SPS are able to follow and comprehend scientific progress and engage in decision-making processes concerning science related matters (Miles, 2010).

Research data reveal that the development of SPS contributes to the overall enhancement of students' performance both in science (Aktamış and Ergin, 2008; Feyzioğlu, 2009; Preece and Brotherton, 1997; Prayitno et al., 2017) and other subject areas (Maranan, 2017), and fosters the cultivation of a positive attitude on their behalf toward scientific research and science lessons (Bilgin, 2006; Zeidan and Jayosi, 2015).

\section{School Science Textbooks}

In formal education, the learning process in many educational systems revolves around the school textbooks, making them a dominant, fundamental teaching tool (McDonald, 2016). School textbooks shape not only the knowledge which students acquire (Yang et al., 2019) but also influence teachers toward implementing specific teaching strategies (McDonald, 2016; Ogan-Bekiroglu, 2007; Wang and Clarke, 2014). School textbooks serve as a starting point for the activities carried out in classroom, often providing guidance and navigating the teaching procedure (Lumpe and Beck, 1996).

Research studies have indicated that $90 \%$ of the science teachers use the school textbooks not only to carry out their lesson but also to assign tasks (questions, activities) to the students (Chiappetta et al., 2006). In fact, it has been reported that for six out of ten science teachers, school textbooks serve as the exclusive teaching material they use in classroom (Banilower et al., 2018).

The activities included in science school textbooks comprise a significant part of their content. These activities establish the important parts for students to learn and are also often used by teachers to evaluate students' performance (Overman et al., 2013). Therefore, evaluating these activities is of great significance.

\section{LITERATURE REVIEW}

Bearing in mind the essential role that SPS hold in science education, the need to examine whether the activities included in school science textbooks provide students opportunities to develop these skills holds a strong argument (Aldahmash et al., 2016; NRC, 2000; Yang et al., 2019).

The existing international literature is rich in studies assessing the content of school science textbooks (Chen and Eilks, 2019; Papageorgiou et al., 2019; Vojír and Rusek, 2019). Among these, studies focusing on the inquiry processes involved in school textbooks' content are included. More specifically, research has been conducted analyzing the activities included in school science textbooks in terms of their efficiency in teaching inquiry processes (German et al., 1996; Tamir and Lunetta, 1978, 1981). Other studies have focused on evaluating the "openness" level of the inquiry-based activities included in school textbooks. To this regard, specific frameworks have been proposed examining whether the problems, steps, materials, and outcomes of the inquiry are provided in advance or are left to be figured out by the students (Bell et al., 2005; Bulunuz et al., 2012; Fay et al., 2007; Germann et al., 1996; Herron, 1971; Lederman, 2009; Schwab, 1962; Wenning, 2007). Some studies focused on the educational functions of the inquiry-based activities included in school textbooks (Millar, 2009). Another part of the research held in this area also turned its interest in evaluating the representation of the essential features of scientific inquiry, as defined from the NRC (1996), as these may appear in school science textbooks. According to the results of these studies, Irish, Turkish, and Saudi Arabian school textbooks failed to include sufficiently the essential features of inquiry (Aldahmash et al., 2016; Dunne et al., 2013; Kahveci, 2010). Similarly, Yang et al. (2019) examined Chinese Biology school textbooks, coming to the conclusion that only some of the activities included in them actually provided students satisfactory opportunities to engage sufficiently in inquiry processes and develop certain science process skills. 
It should be noted that the aforementioned studies are focused on secondary school textbooks. There is a lack of research regarding primary school textbooks and the activities included in them toward providing students opportunities to get involved with SPS. More importantly to the present study, there is a lack of research addressing Greek school textbooks despite their prominent role in the Greek educational system. That being said, carrying out research on Greek science school textbooks in relation to the involvement of SPS in their content appears to be necessary, since there is no data concerning this matter.

\section{METHODOLOGY}

\section{Aim and Research Questions}

The aim of the present study was to determine whether and to what extent the activities included in Greek science school textbooks of the last two primary school grades involve science process skills. More specifically, the following research question is addressed: are SPS involved in the activities included in Greek science school textbooks of the last two primary school grades (for students aged 11 and 12), and if so, to what extent?

\section{Design of the Study}

The present study was conducted using content analysis, a wellestablished and commonly applied method for the evaluation of school textbooks' content (Krippendorff, 2013). This method is consistent with the purpose of the current research, as it allows the analysis of the activities included in the school textbooks examined.

The teaching material to be analyzed was initially identified and, subsequently, the analysis framework to guide the research was selected. Based on this framework the analysis of the activities and the extraction of the results and conclusions followed.

\section{The Teaching Material Analyzed and Units of Analysis}

The activities included in the school science textbooks of the last two Greek primary school grades (for students aged 11 and 12) constituted the sample of the study. These particular school grades were chosen because at this point in time students are introduced to a more regular and systematic exposure to science. Every problem, question, and labwork task included in the two textbooks was considered a unit of analysis. More specifically, a total of 534 activities were analyzed, 232 of which were included in the textbook of the $6^{\text {th }}$ grade, whereas 302 in the textbook of the $5^{\text {th }}$ grade.

\section{Analysis Framework}

A part of the instrument "Inquiry-based Task Analysis Inventory" (ITAI) was selected as the framework to conduct the current research. This instrument was developed aiming to assess the content of school science textbooks in China (Yang and Liu, 2016; Yang et al., 2019). The instrument focuses on evaluating the involvement of 12 science process skills in the activities included in school textbooks, as presented in Table 2.
Table 2: Scoring Rubrics of the Inquiry-Based Task Analysis Inventory (Yang and Liu, 2016, p.23)

\begin{tabular}{|c|c|}
\hline Skills & Scoring Rubrics \\
\hline Observing & $\begin{array}{l}\text { If students are required to or must perform } \\
\text { observation, mark YES, otherwise mark NO }\end{array}$ \\
\hline Inferring & $\begin{array}{l}\text { If students are required to or must infer, mark } \\
\text { YES, otherwise mark NO }\end{array}$ \\
\hline Measuring & $\begin{array}{l}\text { If students are required to or must measure } \\
\text { the variables directly related to research } \\
\text { questions, mark YES, otherwise mark NO }\end{array}$ \\
\hline Communicating & $\begin{array}{l}\text { If students are required to or must } \\
\text { communicate as part of this task, mark YES, } \\
\text { otherwise mark NO }\end{array}$ \\
\hline Classifying & $\begin{array}{l}\text { If students are required to or must perform } \\
\text { classifying that is rigorously defined in the } \\
\text { inquiry process (e.g., biological classification), } \\
\text { mark YES, otherwise mark NO }\end{array}$ \\
\hline Predicting & $\begin{array}{l}\text { If students are required to or must predict, } \\
\text { mark YES, otherwise mark NO }\end{array}$ \\
\hline Controlling variables & $\begin{array}{l}\text { If students are required to or must control } \\
\text { variables, mark YES, otherwise mark NO }\end{array}$ \\
\hline Defining operationally & $\begin{array}{l}\text { If the text of this task completely meets } \\
\text { the following three criteria, (1) students } \\
\text { are required to define operationally, (2) no } \\
\text { cookbook procedure examples are provided } \\
\text { in the text, (3) well-defined, scientific, and } \\
\text { pertinent research questions are provided } \\
\text { or students are asked to develop research } \\
\text { questions and no ill-defined, unscientific, and } \\
\text { non-pertinent question examples are provided, } \\
\text { mark YES, otherwise mark NO }\end{array}$ \\
\hline Formulating Hypotheses & $\begin{array}{l}\text { If students are required to or must formulate } \\
\text { hypotheses and this task in fact belongs to } \\
\text { inquiries that necessarily test hypotheses (e.g., } \\
\text { experimental inquiry), mark YES, otherwise } \\
\text { mark NO }\end{array}$ \\
\hline Interpreting data & $\begin{array}{l}\text { If students are required to or must interpret } \\
\text { data, mark YES, otherwise mark NO }\end{array}$ \\
\hline Asking questions & $\begin{array}{l}\text { If students are required to ask research } \\
\text { questions and no ill-defined, unscientific, } \\
\text { or non-pertinent questions or examples are } \\
\text { provided, mark YES, otherwise mark NO }\end{array}$ \\
\hline Formulating models & $\begin{array}{l}\text { If students are required to or must formulate } \\
\text { models, mark YES, otherwise mark NO }\end{array}$ \\
\hline
\end{tabular}

\section{Data Analysis}

Each unit of analysis was examined in terms of the involvement of each of the 12 science process skills according to the analysis framework adopted (Table 2). Based on the ITAI, when a science process skill was found to be involved in an activity, it was rated with a "YES" response, while otherwise it was rated with a "NO" response.

To ensure the reliability of the content analysis, two researchers worked independently on the scoring procedure. The units of analysis were coded and evaluated by the two raters as to whether they involve each of the science process skills. Subsequently, the given responses were compared to determine the level of agreement between them. Any disagreements were resolved through discussion between the two researchers. 


\begin{tabular}{|c|c|c|c|c|c|c|}
\hline \multicolumn{7}{|c|}{$\begin{array}{l}\text { Table 3: Science process skills in the school science } \\
\text { textbooks of the last two primary school grades in } \\
\text { Greece: Frequencies and percentages }\end{array}$} \\
\hline \multirow[t]{2}{*}{$\begin{array}{c}\text { Science Process } \\
\text { Skills }\end{array}$} & \multicolumn{2}{|c|}{$\begin{array}{c}\text { School } \\
\text { Science } \\
\text { Textbook } \\
\text { of the } 5^{\text {th }} \\
\text { Grade }\end{array}$} & \multicolumn{2}{|c|}{$\begin{array}{l}\text { School } \\
\text { Science } \\
\text { Textbook } \\
\text { of the } 6^{\text {th }} \\
\text { Grade }\end{array}$} & \multicolumn{2}{|c|}{ Total } \\
\hline & $f$ & $\%$ & $f$ & $\%$ & $f$ & $\%$ \\
\hline Observing & 221 & 73.1 & 175 & 75.4 & 396 & 74.2 \\
\hline Inferring & 204 & 67.5 & 168 & 72.4 & 272 & 50.9 \\
\hline Measuring & 25 & 8.3 & 6 & 2.6 & 31 & 5.8 \\
\hline Communicating & 302 & 100 & 232 & 100 & 534 & 100 \\
\hline Classifying & 48 & 15.9 & 48 & 20.7 & 96 & 18 \\
\hline Predicting & 0 & 0 & 5 & 2.2 & 5 & 0.9 \\
\hline Controlling variables & 2 & 0.7 & 0 & 0 & 2 & 0.4 \\
\hline Defining operationally & 0 & 0 & 0 & 0 & 0 & 0 \\
\hline Formulating hypotheses & 40 & 13.2 & 8 & 3.4 & 48 & 9 \\
\hline Interpreting data & 13 & 4.3 & 8 & 3.4 & 21 & 3.9 \\
\hline Asking questions & 11 & 3.6 & 3 & 1.3 & 14 & 2.6 \\
\hline Formulating models & 35 & 11.6 & 24 & 10.3 & 59 & 11 \\
\hline
\end{tabular}

On completion of the analysis, the frequencies of the "YES" and "NO" responses for each activity per science process skill were calculated and expressed as a percentage. An example presenting the analysis of an activity in relation to the science process skills it involves can be found in the Appendix.

\section{RESULTS}

Table 3 displays the involvement of each of the science process skills in the activities included in the textbooks analyzed, expressed both as a frequency and as a percentage.

As shown in Table 3, the results indicated a frequent involvement of the skills of observing, communicating, and inferring in the content of the school textbooks. In fact, the skill of communicating was involved in all of the activities of both textbooks examined. However, the involvement of the skills of classifying, measuring, formulating hypotheses, and formulating models was rather limited. Furthermore, the skills of predicting, controlling variables, interpreting data, and asking questions were rarely involved. The skill of defining operationally was not involved in any of the activities in the two textbooks.

\section{DISCUSSION AND CONCLUSIONS}

The results demonstrated that the involvement of SPS in the school textbooks examined does not follow a balanced distribution, as certain skills were more frequently and to a greater extent involved than others. Therefore, the development of all SPS among students was not equally promoted. In addition, most of the SPS were rarely involved in the activities of the school textbooks.

These results (unbalanced distribution, and limited involvement of some of the SPS) are consistent with the previous research findings on different countries' secondary school science textbooks (Aldahmash et al., 2016; Germann et al., 1996; Tamir and Lunetta, 1978, 1981; Tamir and Pillar-Garcia, 1992; Yang et al., 2019).

In conclusion, the science textbooks of the fifth and sixth Greek primary school grades do not provide opportunities for students to develop all of the SPS and become familiar with them. However, current educational approaches have turned their focus on getting students involved in finding solutions in real life problems, by raising questions, and working on them, designing and conducting investigations, collecting, analyzing and interpreting data, drawing conclusions and sharing the findings (Kruit et al., 2018b; Marannan, 2017). Therefore, this marks a shift of the emphasis from the acquisition of science knowledge toward familiarity with the scientific inquiry procedures (Kanari and Millar, 2004; NRC, 2012). The rare inclusion of certain science process skills in the content of Greek school textbooks, or even their complete exclusion, might negatively affect students' scientific literacy, cognitive development, academic achievements, and development of understanding of the nature of science. Research data reveal that the development of SPS among students facilitates a better understanding of science ideas and concepts (Aktamış and Ergin, 2008; Feyzioğlu, 2009; Preece and Brotherton, 1997; Prayitno et al., 2017) and is apparently associated with fostering students' positive attitudes toward science lessons and scientific inquiry (Bilgin, 2006; Zeidan and Jayosi, 2015).

Consequently, enriching the content of Greek science school textbooks with activities more extensively involving all of the SPS is considered necessary. An adequate involvement of these skills will allow students to become more familiar with them and improve their degree of understanding of science content.

It should be noted that the analysis carried out in the current research focused exclusively on the school textbooks' content, without taking into account any teaching implementation methods of such content in the classroom. This fact constitutes a limitation of this study. It is therefore suggested to conduct research evaluating to what extent teaching held in classrooms involves SPS. In addition, to broaden our acquired knowledge on the involvement of SPS in Greek school textbooks, it is necessary to expand the research on secondary education school science textbooks and compare the results of such research with the ones derived from the current study. It would also be interesting to investigate the SPS level among Greek students. Finally, another suggestion would be to develop teaching material aiming to enhance students' SPS, design an instructional intervention applying this material and conduct research to determine how this instructional intervention contributed to students' level of SPS development.

\section{REFERENCES}

Aktamış, H., \& Ergin, Ö. (2008). The effect of scientific process skills education on students' scientific creativity, science attitudes and academic achievements. Asia-Pacific Forum on Science Learning and Teaching, 9(1), 1-21. 
Aldahmash, A.H., Mansour, N.S., Alshamrani, S.M., \& Almohi, S. (2016). An analysis of activities in Saudi Arabian middle school science textbooks and workbooks for the inclusion of essential features of inquiry. Research in Science Education, 46(6), 879-900.

Banilower, E.R., Smith, P.S., Malzahn, K.A., Plumley, C.L., Gordon, E.M., \& Hayes, M.L. (2018). Report of the 2018 NSSME+. Chapel Hill, NC: Horizon Research, Inc.

Beaumont-Walters, Y., \& Soyibo, K. (2001). An analysis of high school students' performance on five integrated science process skills. Research in Science and Technological Education, 19(2), 133-145.

Bell, R.L., Mulvey, B.K., \& Maeng, J.L. (2012). Beyond understanding: Process skills as a context for nature of science instruction. In: Khine, M. S. (Ed.), Advances in Nature of Science Research: Concepts and Methodologies. Berlin: Springer. pp. 225-245.

Bell, R.L., Smetana, L., \& Binns, I. (2005). Simplifying inquiry instruction: Assessing the inquiry level of classroom activities. The Science Teacher, 72(7), 30-33.

Bilgin, I. (2006). The effects of hands-on activities incorporating a cooperative learning approach on eight grade students' science process skills and attitudes toward science. Journal of Baltic Science Education, $1(9), 27-37$

Brotherton, P.N., \& Preece, P.F. (1995). Science process skills: Their nature and interrelationships. Research in Science and Technological Education, 13(1), 5-11.

Bulunuz, M., Jarrett, O.S., \& Martin-Hansen, L. (2012). Level of inquiry as motivator in an inquiry methods course for preservice elementary teachers. School Science and Mathematics, 112(6), 330-339.

Çakır, N.K., \& Sarıkaya, M. (2010). An evaluation of science process skills of the science teaching majors. Procedia Social and Behavioral Sciences, 9, 1592-1596.

Chabalengula, V.M., Mumba, F., \& Mbewe, S. (2012). How pre-service teachers' understand and perform science process skills. Eurasia Journal of Mathematics, Science and Technology Education, 8(3), 167-176.

Chiappetta, E., Ganesh, T., Lee, Y., \& Phillips, M. (2006). Examination of Science Textbook Analysis Research Conducted on Textbooks Published Over the Past 100 Years in the United States. San Francisco, CA: Paper Presented at the Annual Meeting of the National Association for Research in Science Teaching.

Chen, X., \& Eilks, I. (2019). An analysis of the representation of practical work in secondary chemistry textbooks from different Chinese communities. Science Education International, 30(4), 354-363.

Dökme, İ., \& Aydınlı, E. (2009). Turkish primary school students' performance on basic science process skills. Procedia-Social and Behavioral Sciences, 1(1), 544-548.;

Dunne, J., Mahdi, A.E., \& O'Reilly, J. (2013). Investigating the potential of Irish primary school textbooks in supporting inquiry-based science education (IBSE). International Journal of Science Education, 35(9), 1513-1532.

Fay, M.E., Grove, N.P., Towns, M.H., \& Bretz, S.L. (2007). A rubric to characterize inquiry in the undergraduate chemistry laboratory. Chemistry Education Research and Practice, 8(2), 212-219.

Feyzioğlu, B. (2009). An investigation of the relationship between science process skills with efficient laboratory use and science achievement in chemistry education. Journal of Turkish Science Education, 6(3), 114-132.

Feyzioğlu, B., Demirdag, B., Akyildiz, M., \& Altun, E. (2012). Developing a science process skills test for secondary students: validity and reliability study. Educational Sciences: Theory and Practice, 12(3), 1899-1906.

Germann, P.J., Haskins, S., \& Auls, S. (1996). Analysis of nine high school biology laboratory manuals: Promoting scientific inquiry. Journal of Research in Science Teaching, 33(5), 475-499.

Herron, M.D. (1971). The nature of scientific enquiry. The School Review, $79(2), 171-212$.

Kahveci, A. (2010). Quantitative analysis of science and chemistry textbooks for indicators of reform: A complementary perspective. International Journal of Science Education, 32(11), 1495-1519.

Kanari, Z., \& Millar, R. (2004). Reasoning from data: How students collect and interpret data in science investigations. Journal of Research in Science Teaching, 41(7), 748-769.

Krippendorff, K. (2013). Content Analysis. An Introduction to its Methodology. $3^{\text {rd }}$ ed. Thousand Oaks, California: Sage Publications.
Kruit, P.M., Oostdam, R.J., van den Berg, E., \& Schuitema, J.A. (2018a) Assessing students' ability in performing scientific inquiry: Instruments for measuring science skills in primary education. Research in Science and Technological Education, 36(4), 413-439.

Kruit, P.M., Oostdam, R.J., van den Berg, E., \& Schuitema, J.A. (2018b). Effects of explicit instruction on the acquisition of students' science inquiry skills in grades 5 and 6 of primary education. International Journal of Science Education, 40(4), 421-441.

Lederman, J.S. (2009). Teaching Scientific Inquiry: Exploration, Directed, Guided, and Open-ended Levels. In National Geographic Science: Best Practices in Science Education. Available from: http://www. ngspscience.com/profdev/Monographs/SCL22-0439A_SCI_AM_ Lederman_lores.pdf.

Lumpe, A.T., \& Beck, J. (1996). A profile of high school biology textbooks using scientific literacy recommendations. The American Biology Teacher, 58(3), 147-153.

Maranan, V.M. (2017). Basic Process Skills and Attitude Toward Science: Inputs to an Enhanced Students' Cognitive Performance. San Pablo City Campus: Unpublished Thesis, The Faculty of Graduate Studies and Applied Research, Laguna State Polytechnic University. Available from: https://www.files.eric.ed.gov/fulltext/ED579181.pdf.

McDonald, C.V. (2016). Evaluating junior secondary science textbook usage in Australian schools. Research in Science Education, 46(4), 481-509.

Miles, E. (2010). In-Service Elementary Teachers' Familiarity, Interest, Conceptual Knowledge, and Performance on Science Process Skills. (Unpublished Master Thesis. Southern Illinois University Carbondale, USA. Available from ProQuest, UMI Dissertations Publishing). (UMI No. 1482656)

Millar, R. (2009). Analysing Practical Activities to Assess and Improve Effectiveness: The Practical Activity Analysis Inventory. Centre for Innovation and Research in Science Education, Department of Educational Studies, University of York.

National Research Council. (1996). National Science Education Standards. Washington, DC: National Academy Press.

NRC. (2000). Inquiry and the National Science Education Standards: A Guide for Teaching and Learning. Washington, DC: National Academies Press.

NRC. (2012). A Framework for K-12 Science Education: Practices, Crosscutting Concepts, and Core Ideas. Washington, DC: National Academies Press.

OECD. (2017). PISA 2015 Assessment and Analytical Framework: Science, Reading, Mathematic, Financial Literacy and Collaborative Problem Solving. Paris, France: OECD Publishing.

Ogan-Bekiroglu, F. (2007). To what degree do the currently used physics textbooks meet the expectations? Journal of Science Teacher Education, 18(4), 599-628.

Overman, M., Vermunt, J.D., Meijer, P.C., Bulte, A.M., \& Brekelmans, M. (2013). Textbook questions in context-based and traditional chemistry curricula analysed from a content perspective and a learning activities perspective. International Journal of Science Education, 35(17), 29542978.

Özgelen, S. (2012). Students' science process skills within a cognitive domain framework. Eurasia Journal of Mathematics, Science and Technology Education, 8(4), 283-292.

Padilla, M.J. (1990). The Science Process Skills Research Matters to the Science Teacher, No. 9004. National Association for Research in Science Teaching. Available from: https://www.narst.org/researchmatters/science-process-skills.

Papageorgiou, G., Amariotakis, V., \& Spiliotopoulou, V. (2019). Developing a taxonomy for visual representation characteristics of submicroscopic particles in chemistry textbooks. Science Education International, 30(3), 181-193.

Prayitno, B.A., Corebima, D., Susilo, H., Zubaidah, S., \& Ramli, M. (2017). Closing the science process skills gap between students with high and low level academic achievement. Journal of Baltic Science Education, 16(2), 266-277.

Preece, P.F., \& Brotherton, P.N. (1997). Teaching science process skills: Long-term effects on science achievement. International Journal of Science Education, 19(8), 895-901.

Schwab, J.J. (1962). The teaching of science as enquiry. In: Schwab, J.J., \& 
Brandwein, P.F., (Eds.), The Teaching of Science. Harvard University Press: Harvard University Press. pp. 1-103.

Shahali, E.H., Halim, L., Treagust, D.F., Won, M., \& Chandrasegaran, A.L. (2017). Primary school teachers' understanding of science process skills in relation to their teaching qualifications and teaching experience. Research in Science Education, 47(2), 257-281.

Tamir, P., \& Lunetta, V.N. (1978). An analysis of laboratory inquiries in the BSCS yellow version. The American Biology Teacher, 40(6), 353-357.

Tamir, P., \& Lunetta, V.N. (1981). Inquiry-related tasks in high school science laboratory handbooks. Science Education, 65(5), 477-484.

Tamir, P., \& Pilar-Garcia, M. (1992). Characteristics of laboratory exercises included in science textbooks in Catalonia (Spain). International Journal of Science Education, 14(4), 381-392.

Tilakaratne, C.T.K., \& Ekanayake, T.M.S. (2017). Achievement level of science process skills of junior secondary students: Based on a sample of grade six and seven students from Sri Lanka. International Journal of Environmental and Science Education, 12(9), 2089-2108.

Vojiŕ, K., \& Rusek, M. (2019). Science education textbook research trends:
A systematic literature review. International Journal of Science Education, 41(11), 1496-1516.

Wang, F., \& Clarke, A. (2014). The practicum experiences of English language major student teachers during a period of profound curriculum reform in China. International Journal of Educational Development, 36 , 108-116.

Wenning, C.J. (2007). Assessing inquiry skills as a component of scientific literacy. Journal of Physics Teacher Education Online, 4(2), 21-24.

Yang, W., \& Liu, E. (2016). Development and validation of an instrument for evaluating inquiry-based tasks in science textbooks. International Journal of Science Education, 38(18), 2688-2711.

Yang, W., Liu, C., \& Liu, E. (2019). Content analysis of inquiry-based tasks in high school biology textbooks in Mainland China. International Journal of Science Education, 41(6), 827-845.

Zeidan, A.H., \& Jayosi, M.R. (2015). Science process skills and attitudes toward science among Palestinian secondary school students. World Journal of Education, 5(1), 13-24.

\section{An Analysis of an Activity: An Example} Activity (School science textbook of the 5th grade)

For this experiment you will need a watch with a second hand.

(a) Count your pulses for one minute, while you remain seated.

(b) Repeat the measurement after running in place for a few minutes.

Observations:

Ask one of your classmates to keep time while you count your pulses:

\begin{tabular}{lll}
\hline & NAME & \multicolumn{2}{l}{ PULSES PER MINUTE } \\
\cline { 2 - 2 } & AT REST & AFTER RUNNING \\
\hline 1 & \\
2 & \\
3 & \\
4 & \\
5 & \\
6 & \\
\hline
\end{tabular}

Conclusion:

Write your conclusion using the words: Pulse, heart, exercise, rhythm

\section{Analysis}

\begin{tabular}{lc}
\hline Science Process & Score \\
Skills & \\
\hline Observing & Yes \\
Inferring & Yes \\
Measuring & Yes \\
Communicating & Yes \\
Classifying & No \\
Predicting & No \\
Controlling Variables & No \\
Defining operationally & No \\
Formulating hypotheses & No \\
Interpreting data & Yes \\
Asking questions & No \\
Formulating models & No \\
\hline
\end{tabular}

